\title{
MANAGING GROUP WORK IN THE CLASSROOM: AN INTERNATIONAL STUDY ON PERCEIVED BENEFITS AND RISKS BASED ON STUDENTS' CULTURAL BACKGROUND AND GENDER*
}

\author{
Maja Šerić ${ }^{* *}$ \\ Daniela Garbin Praničevic ${ }^{* * *}$
}

Received: 19. 10. 2017

Preliminary communication

Accepted: 27. 5. 2018

UDC 37.02-057.875

DOI https://doi.org/10.30924/mjcmi/2018.23.1.139

\begin{abstract}
Working in groups has become an essential part of success of every organization operating in global economy. Therefore, the business sector has created an imperative for higher education institutions (HEIs) to modify study programs and prepare students to be effective team players. However, while group work has been highly encouraged among university students, their opinions on this practice remain rather neglected. In addition, the role of culture and gender in students' perceptions of group work has received little attention. The purpose of this study is to examine how university students perceive group work in terms of its benefits and risks and whether their national culture and gender moderates these
\end{abstract}

\section{INTRODUCTION}

Group work has been defined as 'pupils working together as a group or a team' (Blatchford et al., 2003, p. 155). This method has been integrated in numerous educational programs. The reasons are many, although perceptions. Both qualitative and quantitative research methods were employed to meet the research goal. Data were collected among Spanish, Croatian and international students from two European universities: University of Valencia in Spain and University of Split in Croatia. Results suggest that, although students seem to recognize the benefits of group work, they also perceive a considerable number of risks, especially Croatian students. This might be the reason why they don't seem to prefer group work over individual work, despite their cultural background and gender.

Keywords: group work, benefits, risks, focus group, international students, Spain, Croatia, culture, gender.

the most frequently mentioned ones are the following two: a) group work practiced in classroom provides students with opportunities to acquire basic collaboration skills and therefore gain valuable experience before graduating (Chowdhury et al., 2002), and b) group work integrated in management

\footnotetext{
* This work has been developed under the projects of innovative education UV-SFPIE_RMD16-418989 and UVSFPIE_RMD17-588810, funded by University of Valencia, the Office of the Vice-Principal for Training Policies and Educational Quality.

${ }^{* *}$ Maja Šerić, University of Valencia, Department of Marketing, Av. de los Naranjos s/n, 46022 Valencia, Spain, e-mail: maja.seric@uv.es

*** Daniela Garbin Praničević, University of Split, Faculty of Economics, Business and Tourism, Cvite Fiskovića 5, 21000 Split, Croatia, e-mail: daniela.garbin.pranicevic@efst.hr
} 
education prepares students to achieve higher work efficiency, improve the related business processes, define achievable strategy, and generally manage the company more professionally upon their introduction in real business (Guzzo and Dickson. 1996). In order to prepare for facing those challenges, group work has been implemented in many organizations globally (Ettington and Camp, 2002; Frobel and Marchington, 2005). This methodology practice has been rising constantly and over time has expanded also virtually (Gressgård, 2011).

Different types of group work have been identified in literature, i.e. (top) management groups, action groups, and virtual groups. While management groups rely on highinvolvement of members in task coordination and joint problem solving, action groups are formed to address unexpected events or emergencies. Finally, virtual groups work with different levels of interaction synchronicity in virtual settings (Hollenbeck et al., 2012; West, 2012; Zijlstra et al., 2012).

Students' attitudes toward group work differ and depend on their ability to work in groups, i.e. their self-efficacy (Chowdhury et al., 2002), which, onwards, results in higher or lower individual satisfaction and individual performances on the group level. Some studies were focused on exploring self-efficacy with intention to improve both individual and organizational performances (e.g. Gist and Mitchell, 1992). Literature suggests that a particular group member may be satisfied with the group environment despite lower group performance (Landy, 1989). Chowdhury et al. (2002) also revealed that group performance has a potential of acting as a moderator of the relationships between self-efficacy of working in a team environment and individual outcome variables, namely satisfaction with a group and individual performance in a group.
Pineda et al. (2009) argued whether the education institutions are really taking appropriate steps to prepare students to become effective team members and encourage the university educators to reconsider and perform pedagogical skills to facilitate a positive group work experience among their students on an international level. The objective of this paper is to provide some new insights on these issues by examining student's perceptions of group work benefits and risks from cross-cultural perspective. It should be noted that cross-cultural studies on group work mostly involved students from western and eastern countries (e.g. Pineda et al., 2009; Takeuchi et al., 2013; Duus and Cooray, 2014) or Asian countries (e.g. Collins et al., 2017), while differences among students from European countries were rather neglected. This work attempts to meet this gap. In addition, it considers gender as another diversity factor when explaining results.

The paper is structured in the following way. After the introduction presented at the beginning, literature review on group work is discussed in the second section. In the third section, the methodology of our empirical study is explained, followed by analysis and discussion of results. Conclusions and implications of the work are presented in the final part.

\section{LITERATURE REVIEW}

\subsection{Group work management in the educational context}

Group work is one of the main pillars in each project management as it can significantly influence project outcome (Young, 2009). In the educational context, students that are involved in project-based group work have to design and plan a number of 
complex activities. The collaboration emerges over time as each group member develops an understanding of his or her own role and contribution to the project on one hand, and provides information that allows others to progress, on the other (Fruchtner, 2001).

LePine et al. (2008) discussed group performance through three different processes, namely: action, transition, and interpersonal processes. While the first one centers on progress towards goals, systems monitoring (i.e. tracking team resources), team monitoring, backup behavior and coordination, the second one embraces activities that a group conduct between performance episodes. Finally, interpersonal processes gather activities focused on management of interpersonal relationships.

In order to be effective, group work requires size of about six to eight members with clearly defined roles (West, 2012). Members of the group participate in a common work with clearly defined and measureable goals provided with autonomy, authority and necessary resources. Group tasks are found to be more effective if group members are successors of a previous common working experiences, based primarily on coordination and communication (Cattani, 2013). An appropriate collaboration requires competence, confidence, commitment, respect, and trust between all members of the group (Henneman et al., 1995). Working in groups usually directs student activities towards mapping the space for problems and solutions, synergy of multidisciplinary solutions, and documentation of product evolution and processes. In addition, upon the introduction of Information and Communication Technology (ICT) supporting tools in this process, the improvements are evident in evolution from synchronous to asynchronous communication, which provides an additional value to collaborative dimension of group works (Fruchtner, 2001).
The role of teacher-instructors has been identified as highly important for a successful group work management and performance. Bolton (1999) argued the critical role of instructor in student coaching. Coaching is considered as a process of offering "suggestions, observations, and insights to individual teams on an as-needed, just-in-time basis" (p. 238-239). Accordingly, a number of coaching activities and behaviors are identified, namely: a) starting student teams off on the right foot, which implies clear announcement of purpose, direction, and agenda, personal insights from own experience and creation of a nonjudgmental classroom climate, b) helping teams manage diversity and conflict through several activities, such as encouragement of participation where there is silence, mediation of discussions where there is hostility, being a role model for nonjudgmental delivery of feedback, and c) helping students learn from their group work experience by positing structured questions, asking students personal questions about their own learning and providing a continues encouragement (Bolton, 1999).

Some studies also discussed the importance of group work skills for students' employment after graduation. Thus, in a study on different employment skills (Hodge and Lear, 2011) international students ranked group work as the most important among 15 identified skills, while US students placed it on the third place, after management and interpersonal skills. Faculty members ranked it as the fourth, after interpersonal skills, critical thinking, and problem solving. Similarly, Kavanagh and Drennan (2008) analyzed students' and employers' perceptions of different employment skills, group work being one of them. The results revealed that students acknowledged employers' expectations in terms of communication, analytical, professional and teamwork skills. However, both students and employers highlighted that 
university programs do not encourage sufficiently these skills.

\subsection{Perceived benefits and risks of group work}

A number of group work benefits emerged in the educational management literature, such as: improvement of students' management and communications skills, development of a clear vision of the group culture, understanding of different group roles, and increased flexibility on the individual and group level (Nancarrow et al., 2013). Subsequently, the following three indicators for a positive group work were established: personal qualities and interpersonal skills, communication within the group, and enhanced creativity (Molyneux, 2001; Nancarrow et al., 2013)

Literature also evidences different perceptions related to capabilities of group work. Katinka et al. (2005) examined organizational skills and group work among graduate students from schools with problembased learning study programs (where group work is encouraged) and non-problem-based learning study programs (without group work practice). The results revealed that students from problem-based learning schools showed better preparation with respect to several of the competencies, especially profession-specific methods, communication skills and group work.

Ruiz Ulloa and Adams (2004) found that students are developing positive individual attitudes toward group work, if the particular environment determinants, such as professional communication, interdependence, psychological safety, common vision, defined role and goals, are present during working in group sessions. Falls et al. (2014) concluded that students' perception of group work is influenced by personal factors and that this perception affects student performance as group members.

When group work was examined in a digital context, Powell et al. (2004) found that students' positive perception of virtual online group work increased as they attended more online courses, thus participating more actively in associated virtual teams. Moreover, Goold et al. (2006) found that students mainly used discussion forums for working online, together with email, chat and face-to-face meetings. Among benefits of online group work, the most frequently mentioned were: possibility to record communication and participation, flexibility of time and place, and an 'efficient' way of working.

Nevertheless, some studies showed that students do not always have positive attitudes toward group work, due to the perceived relationship between group work and effective performance. In this vein, McCorkle et al. (1999) claimed that although most students were aware of the importance of group work, some still preferred to work alone when the main goal was achieving high performance. Peslak (2005) examined emotions of students who participated in a long-term project and found that, although team emotions in the beginning of the project were more positive than negative, negative emotions prevailed over time. Similarly, the study of Goold et al. (2006) revealed that $15 \%$ of students didn't like online group work because of communication difficulties and owing to the fact that members leave participation and submission to the last minute. Moreover, frustration increased when other students were not involved as expected. Accordingly, some students believed that they had done more work than other group members. This phenomenon is named "social loafing" and it suggests that people tend to make less effort when they work in a group than when they work individually. Therefore, making 
students work together often implies unequal participation and an unfair share of responsibilities (Terveen and McDonald, 2005).

\section{METHODOLOGY}

The purpose of this work is to obtain students' insights on group work in an international environment and examine whether these can change according to the culture and gender of participants. Culture and gender approach were included as critical diversity factors that are found to shape students' perceptions (Pineda et al., 2009; Van Knippenberg et al., 2004; Nell and Cant, 2014) and, as such, are found to have implications on the management level (Dwyer et al., 2003).

Considering all the insights mentioned above, the following research aims are proposed:

RA1: Understand benefits that students perceive from group work.

RA2: Understand risks that students perceive from group work.

RA3: Observe how culture moderates perceived benefits and risks of group work.

RA4: Observe how gender moderates perceived benefits and risks of group work.
Students of the Faculty of Economics from two Universities participated in the study: University of Valencia in Spain and University of Split in Croatia. The empirical research was conducted in NovemberDecember 2016 and April 2017.

Both qualitative and quantitative method were adopted to meet the research goals. Firstly, qualitative analysis, more specifically the focus groups technique, was conducted to understand students' perceived benefits and risks regarding group work. A focus group normally brings together between four and 12 participants to discuss research objectives (Ritchie et al., 2003). The literature suggests the use of a minimum of three to four focus groups to obtain relevant findings (Halcomb et al., 2007). Six focus groups were formed for the purpose of this study: two composed of Spanish students, two composed of Croatian students and another two of international students. As reported in Table 2, 38 students were selected as participants in the focus groups method. The focus groups were established within two courses of the Faculty of Economics at each University (i.e. University of Valencia in Spain and University of Split in Croatia, respectively) and were conducted during the scheduled classes for each course. The groups' participants were selected on the basis of student attendance and different time

\section{Table 1. Focus group participants}

\begin{tabular}{|l|l|}
\hline \multicolumn{2}{|c|}{ FOCUS GROUP } \\
\hline \multicolumn{2}{|c|}{ SPANISH } \\
\hline 1 & 4 participants: 3 female and 1 male \\
\hline 2 & 8 participants: 6 female and 2 male \\
\hline \multicolumn{2}{|c|}{ CROATIAN } \\
\hline 3 & 6 participants: 4 female and 2 male \\
\hline 4 & 6 participants: 4 female and 2 male \\
\hline \multicolumn{2}{|c|}{ INTERNATIONAL } \\
\hline 5 & $\begin{array}{l}\text { 8 participants: 1 Brazilian male, 1 USA male, 1 Taiwan female, 1 Belgium male, } 1 \\
\text { Dutch male, 1 Korean female, 1 Belgium female, 1 Danish female }\end{array}$ \\
\hline 6 & 6 participants: 3 French female, 2 Polish female, 1 Italian male \\
\hline
\end{tabular}


schedules of each course. Considering the profile of enrolled students, gender diversity was pursued in the formation of Spanish and Croatian focus groups, while with the international groups, cultural diversity was also considered.

Once the qualitative part of the study was conducted, the quantitative analysis was carried out on a group of 195 students from five different courses from two Universities. Among them, 65 (33.3\%) were male and 130 $(66.7 \%)$ were female. A total of 70 students (35.9\%) were Spanish, 50 (25.6\%) were from Croatia, while the rest $(38.5 \%)$ were international students. Among the latter, the most representative group was composed by German students $(7.7 \%)$, followed by Italian (4.1\%), Dutch (3.6\%), French (3.6\%), Polish (2.6\%), British (2.1\%) and Austrian (2.1\%) students (see Table 2). The participants were mostly between 21 and 23 years old $(65.1 \%)$. They attended graduate $(55.4 \%)$ and postgraduate $(44.6 \%)$ degree programs.

Table 2. Profile of respondents: culture and gender

\begin{tabular}{|l|c|c|}
\hline \multicolumn{3}{|l|}{ PROFILE OF RESPONDENTS (N=195) } \\
\hline & Frequency & \% \\
\hline CULTURE \\
\hline Spanish & 70 & 35.9 \\
\hline Croatian & 50 & 25.6 \\
\hline International & 75 & 38.5 \\
\hline GENDER \\
\hline Male \\
\hline Female & 130 & 66.7 \\
\hline AGE & 23 \\
\hline $18-20$ & 23 & 11.8 \\
\hline 21-23 & 127 & 65.1 \\
\hline 24-26 & 39 & 20.0 \\
\hline More than 26 & 6 & 3.1 \\
\hline DEGREE & 108 & 55.4 \\
\hline Graduate & 87 & 44.6 \\
\hline Postgraduate & \multicolumn{2}{|l}{} \\
\hline \multicolumn{2}{|l|}{} \\
\hline
\end{tabular}

\section{RESULTS}

\subsection{Focus groups: summary of findings per group}

The first two focus groups were composed of Spanish students. The first one consisted of four students', three female and one male. One male and one female participant stressed the benefit of creating synergies despite individual differences of group members. Two male participants stressed a benefit of achieving better results and a risk of being under pressure if other team members were highly involved. Female participants were more focused on risks of having a leader who doesn't respect the opinions of other members. One male participant of this group proposed peer evaluation of the group to increase the involvement of its members.

The second focus group of Spanish students was composed of eight participants (six female students and two male students). The qualitative analysis of this focus group was discussed in a study of Šerić and Garbin Praničević (2017). Two main benefits of group work were mentioned: meeting new people and obtaining peer support. These benefits were found to be influenced by attitudes of other group members. The possibility of "being embarrassed by doing nothing" emerged as a main risk. An anonymous evaluation of the peers was also proposed as a control system by one female participant.

The third and the fourth focus groups consisted of Croatian participants. The third group was composed of six participants: four female students and two male students. While female participants perceived entertainment, synergy effects and better topic elaboration as main benefits of group work, male participants stressed mutual support and motivation between team members, as well as time efficiency. Risks were mostly discussed among female participants. 
Unbalanced task distribution, possible conflict situations and different team members' working styles came up as the most important factors. An interesting finding about this focus group are the opposite approaches towards the selection of group work members. While some believed that this task should be performed by the teacher, others thought that students should form a group on their own, as they know each other's skills and capabilities better than a teacher does and, subsequently, can do a better job together. Finally, a clear definition of roles of every team member emerged as highly relevant among male participants.

The fourth focus group was also composed of four female students and two male students, all Croatian students. Within this group, the following group work benefits emerged: a) communication skills development, b) collaborative learning, c) approaching the topic from other people's perspective and d) increased productivity. Male participants pointed out increased motivation and synergies as main benefits. In addition, this group listed a number of perceived risks, such as: a) lack of respect between team members, b) unequal level of engagement, workload and responsibility, c) imposition of opinions of more aggressive members d) lack of consideration for other student's opinion and e) impossibility to choose team members. These risks were almost equally pointed out by both male and female participants. In the context of group work improvements, one participant proposed organizing a pre-activity session with the scope of socializing and providing students a possibility to get to know each other better. Similar to what was mentioned by the previous group, another member stressed the importance of assigning roles to each member of the group, with clear definition of their tasks and responsibilities.
The final two groups consisted of international students. The only thing that these students had in common regarding their nationalities was that they were neither Spanish nor Croatian. In particular, the fifth group consisted of six international students, or more specifically: three female students from France, two female students from Poland and one male student from Italy. The group perceived the following benefits of group work: a) enhanced cooperation, b) higher involvement, c) opportunity to become more-open minded and more creative, and d) opportunity for shy students to develop interpersonal skills. Increased involvement emerged as the main benefit among French students. On the other hand, the main risk of group work that emerged from the discussion is complete lack of involvement by some member(s).

The sixth focus group was composed of eight members: four male students and four female students of different nationalities (Brazil, USA; Denmark, Belgium, Holland, Taiwan, and Korea). Interestingly, two male members of this group identified responsibility as a risk, owing to the fact that members are required to "not let the team down" and work harder, while other male member considered it as a benefit, as in a group the responsibility is divided, which leads to a decrease in workload. Female members highlighted increased involvement as the main benefit of group work. One male student was even concerned about the image of the country of origin, stating: "I tend to go above and beyond in terms of my group work in order to represent my country well". Finally, one female participant suggested that group work should be designed for the purpose of project-based learning, where students are continuously working to meet a project goal. 


\subsection{Focus groups: classification of benefits, risks and suggestions for improvements}

The benefits that emerged from qualitative analysis might be grouped into the following three categories: a) functional (group members' support for clarification of doubts, better performance, better topic elaboration, increased productivity, time efficiency, work division, collaborative learning), b) social (meeting and knowing people, insights on different points of view, synergies with other group members, entertainment, mutual support between team members, increased collaboration) and c) personal (increased motivation, better communication and interpersonal skills, increased involvement, open-mindedness and creativity, greater responsibility).

On the other hand, the risks can be grouped into: a) functional (different working styles of team members, impossibility to choose a group member), b) interpersonal (disrespectful leader, lack of respect between team members, imposition of opinions of more aggressive members, lack of consideration for the opinions of others, possible conflicts between group members, c) personal (being embarrassed, increased pressure, greater responsibility), and d) perceived inequality (unbalanced task distribution, unequal level of engagement, workload and responsibility).

Some improvements for more efficient team management were suggested by students upon identification of risks: These are a) peer evaluation of group members, where each group member evaluates other member's attitudes and performance, b) clear definition of roles, assignments and responsibilities of each group member, c) organization of a preliminary session with the purpose of getting to know other group members, as well as their capabilities and skills and d) formation of groups for the purpose of the project-based learning, where students learn about subject by working in groups around a project topic.

There are studies that show how female students enrolled in scientific degrees prefer

Figure 1. Focus group findings: Benefits, risks, and suggestions for improvements of group work in classroom

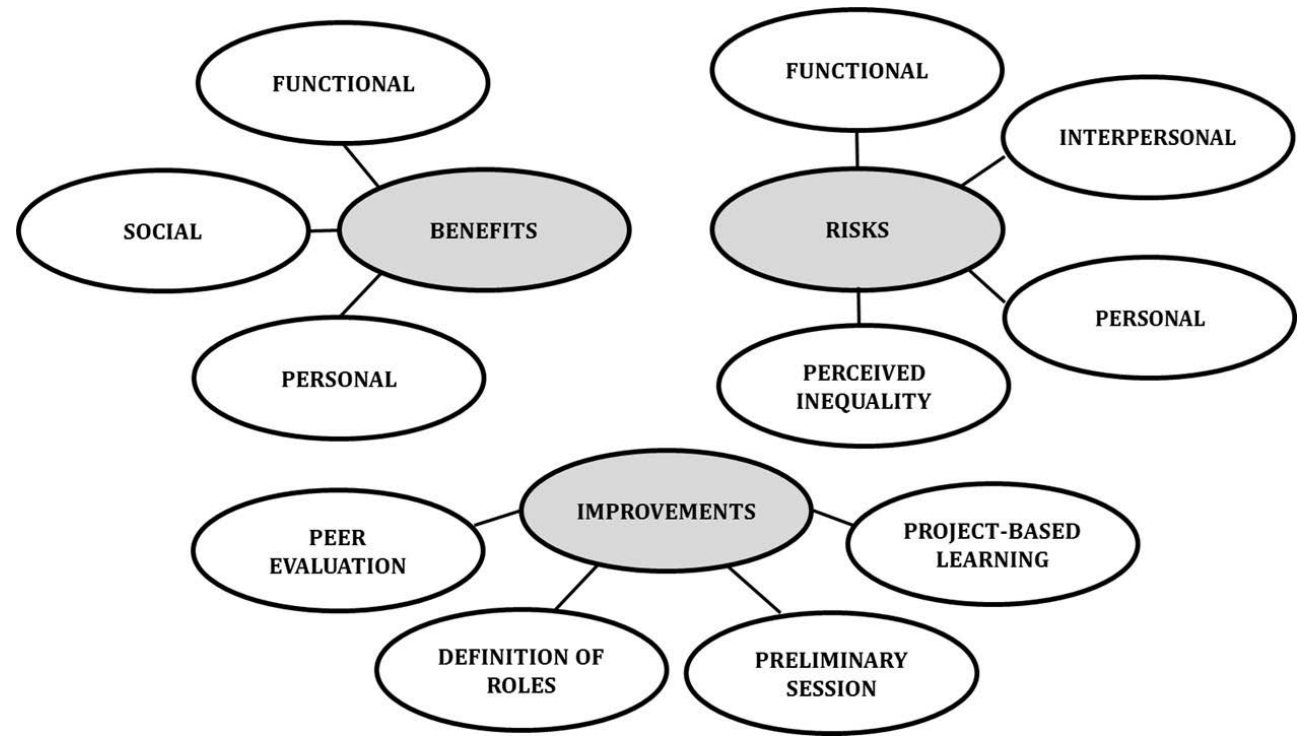


teamwork and gain more educational benefits than males (Fruchtner, 2001; Gist and Mitchell, 1992; Goold, Augar and Farmer, 2006).

\subsection{Focus groups: findings according to students' culture and gender}

Benefits and risks, as well as improvements towards more efficient group work, that emerged from a qualitative analysis are reported in Table 3. Data are classified according to national culture and gender.

Overall, students have reported more benefits of group work than risks. Creation of synergies with other group members, increased motivation and increased communication and interpersonal sills were the most frequently mentioned benefits, while lack of involvement and respect of some group members were the most salient risks.

Interestingly, when three delimited groups were compared according to the culture of origin, students defined benefits, risks and suggestions for improvement of group work management rather differently. Croatian students identified more benefits and risks, compared to their Spanish and international counterparts. While these students were equally concerned about functional and social benefits and, to a lesser extent, about personal benefits, Spanish students were more focused on social benefits, followed by functional and personal. International students were mostly centred on personal benefits and mentioned only one social benefit (i.e. increased collaboration with other students) and not a single functional benefit. In addition, when risks were discussed, Spanish students identified personal and, to a lesser extent, interpersonal risks, while Croatian students mostly identified interpersonal risks, followed by perceived inequality and functional risks, without mentioning any personal risk.
International students mentioned only two risks: lack of involvement (perceived inequality) and greater responsibility (personal risk). Finally, each of the three groups proposed a different suggestion for improvement. While Spanish students suggested peer evaluation of other team members, Croatian students stressed the importance of clear definition of roles and organization of pre-activities aimed at socialization, while international students proposed group work to be a tool for project-based learning.

When gender was considered, female participants identified more benefits and risks than their male counterparts did, while male and female students equally stressed improvements in team work management. Male participants mostly identified social benefits of group work, followed by functional and personal whereas female students mentioned all three types of benefits equally. Regarding risks, male students recognized mostly interpersonal and personal risks, while female students mainly focused on interpersonal risks and perceived inequality. However, both male and female students agreed on some benefits (i.e. synergies with other team members in the Spanish subgroup) and risks (i.e. lack of respect, lack of consideration of opinion of other students and imposition of more aggressive group members, unequal level of engagement, workload and responsibility). All these data are reported in Table 4.

\subsection{Findings of quantitative analysis}

Once the focus groups were conducted, students were asked to identify the aspects of group work that were highly relevant for them. A total of nine items emerged, four related to comparisons of group work with individual work, four related to benefits such as insights on different points of view, improved interpersonal skills, understanding of personal strengths and weaknesses and 
Table 3. Group work in classroom: benefits, risks and suggestions for improvement according to students' culture and gender

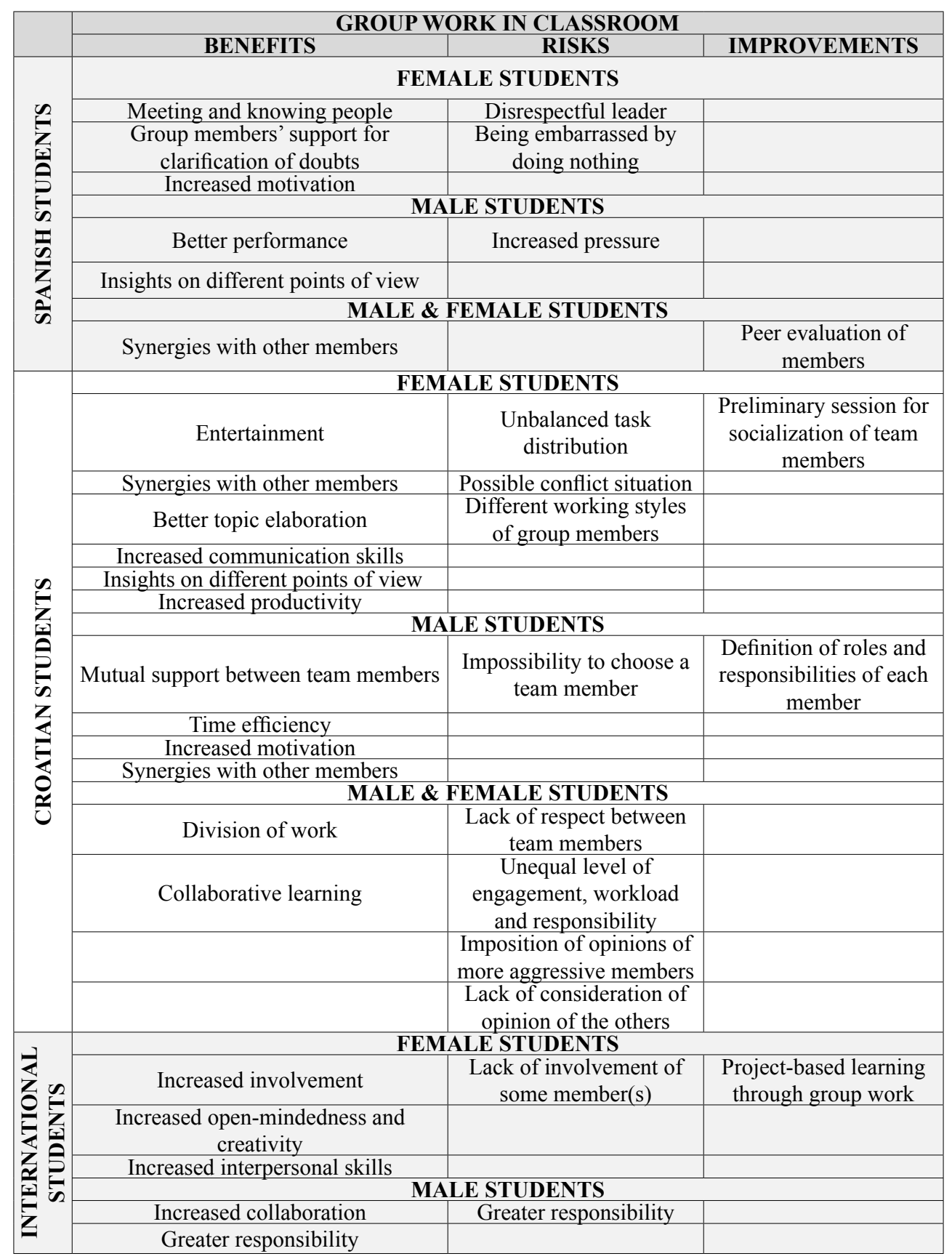


Management, Vol. 23, 2018, No.1, pp. 139-156

M. Šerić, D. Garbin Praničević: MANAGING GROUP WORK IN THE CLASSROOM...

Table 4. Group work in classroom: frequency of mentioned benefits and risks according to students culture and gender

\begin{tabular}{|c|c|c|c|c|c|c|c|}
\hline \multicolumn{8}{|c|}{ GROUP WORK IN CLASSROOM } \\
\hline & \multicolumn{3}{|c|}{ BENEFITS } & \multicolumn{4}{|c|}{ RISKS } \\
\hline CULTURE & Functional & Social & Personal & Functional & $\begin{array}{c}\text { Inter- } \\
\text { Personal }\end{array}$ & Personal & $\begin{array}{l}\text { Perceived } \\
\text { Unfairness }\end{array}$ \\
\hline Spanish & $\mathrm{xx}$ & $\mathrm{xxx}$ & $\mathrm{x}$ & l & $\mathrm{x}$ & $\mathrm{xx}$ & / \\
\hline Croatian & $\mathrm{xxxxx}$ & $\operatorname{xxxxx}$ & $x x$ & $\mathrm{xx}$ & $\operatorname{xxxx}$ & I & $\mathrm{xx}$ \\
\hline International & / & $\mathrm{x}$ & $\operatorname{xxxx}$ & / & / & $\mathrm{x}$ & $\mathrm{x}$ \\
\hline GENDER & Functional & Social & Personal & Functional & $\begin{array}{c}\text { Inter- } \\
\text { Personal }\end{array}$ & Personal & $\begin{array}{l}\text { Perceived } \\
\text { Unfairness }\end{array}$ \\
\hline Male & $\operatorname{xxxx}$ & $\operatorname{xxxxx}$ & $\mathrm{xx}$ & $\mathrm{x}$ & $\mathrm{xxx}$ & $\mathrm{xx}$ & $\mathrm{x}$ \\
\hline Female & $\operatorname{xxxxx}$ & $\operatorname{xxxxx}$ & $\operatorname{xxxxx}$ & $\mathrm{x}$ & $\operatorname{xxxxx}$ & $\mathrm{x}$ & $\mathrm{xxx}$ \\
\hline
\end{tabular}

increased class attendance and subsequent involvement, and only one risk: equal evaluation for all team members. These aspects were further considered for quantitative analysis.

Data were collected through an online structured questionnaire. The validity and reliability of the instrument were assessed by examining item-to-dimension total score correlations and Cronbach alpha, respectively. The validity was confirmed as the corresponding items were found to correlate very well with the scale overall, all being highly significant $(\mathrm{p}=0.000)$. The Cronbach alpha was higher than 0.7 (i.e. 0.818), which confirmed the instrument reliability (Nunnally and Bernstein, 1994). The items were assessed using a 5-point Likert-type scale anchored from 1 (strongly disagree) to 5 (strongly agree). Descriptive statistics analysis was performed, using SPSS software. Data were analysed through descriptive statistics and frequency distributions. When different groups of participants were compared, the Kolmogorov-Smirnov test was first conducted to check the normality of data distribution. The results showed that the data were not normally distributed, as most of the items appeared to have critical values lower than .05 . Thereby, non-parametric tests were conducted for further analysis, more specifically, the Kruskal-Wallis H test for comparing three groups (i.e. Spanish, Croatian and international students) and the Mann-Whitney U test for comparison of two groups (i.e. male and female students).

The results reported in Table 5 suggest that, when the total group of participants was observed $(\mathrm{N}=195)$, students assigned rather moderate scores to most of the items of group work. The items that received the highest score are the perceived benefits related to gaining insights into other persons' perspectives $(\mathrm{M}=4.07)$, improving interpersonal skills $(\mathrm{M}=3.95)$ and identifying personal strengths and weaknesses $(\mathrm{M}=3.94)$. The items that received the lowest scores are "group work is less time consuming than individual work" $(\mathrm{M}=2.84)$ and "preferences for group work rather than individual work" $(M=3.01)$. It should be noted that only one item obtained a mean value slightly higher than four. The analysis of frequencies revealed that the ratings of the first four items were distributed rather evenly, meaning that, in general, differences between the number of times that each score occurred were not as big as in the case of other items. These four 


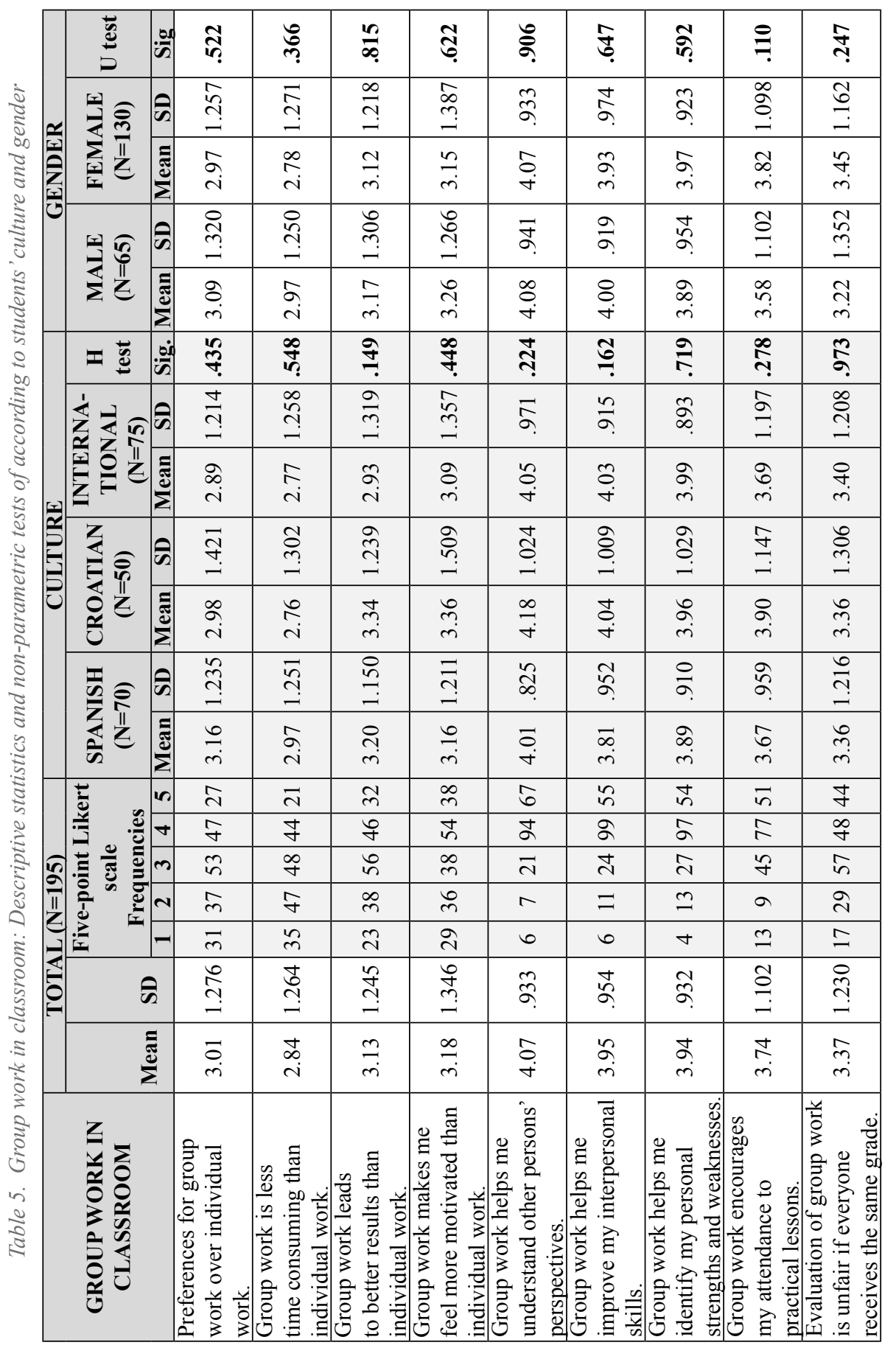


items are as follows: "preferences for group work over individual work", "group work is less time consuming than individual work", "group work leads to better results than individual work, and group work makes me feel more motivated than individual work.

In order to observe whether significant differences exist among students' opinions on group work according to their culture and gender, the Kolmogorov-Smirnov test was first performed in order to check the normality of data distribution. The results showed that the data were not normally distributed, owing to the fact that almost all the examined items had critical values lower than .05 . Thereby, non-parametric tests were adopted for further analysis.

Firstly, the Kruskal-Wallis $\mathrm{H}$ test was employed to compare three independent groups, i.e. Croatian, Spanish and international students. Descriptive statistics analysis revealed that Croatian students evaluated with highest scores most of the group work items (i.e. leads to better results than individual work, helps me understand other persons' perspectives, encourages my attendance, makes me feel more motivated). Spanish students showed a greater preference for group work over individual work and perceived better the time-efficiency of group work than their Croatian and international counterparts did. Still, the $\mathrm{H}$ test revealed that neither one of these differences was statistically significant. In fact, some items were assessed almost equally by the three groups of students (i.e. group work helps me identify my personal strengths and weaknesses and evaluation of group is unfair if everyone receives the same grade).

Secondly, gender was considered for data comparison. Descriptive statistics analysis revealed that male students' assigned higher scores to most of the group work items, while female students positively assessed group work benefits related to increased attendance and understanding personal strengths and weaknesses. Female students also believed, to a greater extent, that evaluation is unfair is every group member receives the same grade. The Mann-Whitney U non-parametric test was completed, comparing two independent groups, to determine whether the obtained differences between male and female students are statistically significant. Results suggest that there were no significant differences in perception of group work items between male and female students.

\section{CONCLUSIONS AND IMPLICATIONS}

The aim of this paper was to understand students' perceived benefits and risks of group work, thus providing important implications for teachers in higher education institutions. Results from the qualitative analysis suggest a number of benefits, which can be grouped into functional, social, and personal benefits, as well as perceived risks, classified into functional, interpersonal, personal, and perceived inequality. Interestingly, when students had to select the most important attributes of group work, they focused on the benefits and reduced all the perceived risks to only one element: unfair final evaluation. To diminish this risk, they stressed the importance of peer evaluation of individual work of each team member, thus providing relevant team management implications for teachers. In addition, lack of involvement of some members was the most frequently mentioned risk of group work. A similar finding was obtained in a study on students' attitudes towards group work conducted by Gottschall and García-Bayonas (2008). These authors found that the so-called "free riders" were the major perceived risk of group work. The role of the teacher is 
critical in addressing this risk. A clear definition of roles of each of the members, their respective assignments and responsibilities as well as the formalization of commitment to work of each team member might help reduce this risk. In particular, teachers who work with Croatian students should do their bests to mitigate inter-personal conflicts as this type of group work risk was mostly observed among Croatian students. In addition, teachers of both Croatian and Spanish students need to stress personal benefits of group work to induce involvement, as these students perceived less personal benefits than their international peers did. Finally, teachers dealing with international students should stress functional and social benefits of group work as these students hardly even perceived any of these benefits.

Results of the quantitative analysis show that students don't seem to prefer group work over individual work that much and that they do not feel more motivated working in groups than working alone. These findings match those obtained by McCorkle et al. (1999), who found that students sometimes prefer individual over group work and that lack of motivation of some members is one of the major problems of a successful group work. This is another important implication for teachers, who need to identify factors that motivate students to work with their colleagues. This might be accomplished by making them care more about the outcomes, creating a group in which members have similar interests and providing an effective system of evaluation to ensure an equal share of responsibilities. In accordance with Ludford et al. (2004), telling students' something unique about their connection to a topic could increase their motivation and participation. In addition, teachers might also introduce entertainment elements in the group work which can affect positively students' motivation and involvement.
Moreover, teachers need to manage group work by providing students a realistic view of how groups function in real organizations, highlighting insights into social processes and team effectiveness. The strength and the importance of an effective team is more important than ever in global business. Therefore, it is essential for students to understand group work methodology as a group process with relevant implications on the organization level.

Focus group analysis suggests the existence of cultural and gender differences regarding students' perceived benefits and risks of group work. This finding broadly supports the work of other studies in this area which found a strong impact of culture (e.g. Pineda et al., 2009) and gender (e.g. Curran et al., 2008) in students' assessment of group work. Thus, Pineda et al. (2009) suggested that students coming from societies with different cultural values could be developing different attitudes to group work owing to their different educational practices and experiences. The finding of Curran et al (2008) revealed that female students showed significantly more positive attitudes towards inter-professional teamwork and inter-professional education than their male counterparts did. However, this outcome is contrary to the results that emerged from our focus groups, which reveal that female students reported more perceived risks of group work than male students.

Nevertheless, our quantitative analysis revealed that students perceived group works items rather similarly, despite their cultural background and gender. This finding is in accordance with some other studies (e.g. Panina and Kroumova, 2015), which suggest that national culture does not always explain differences in students' perceptions and behaviors. Thereby, future contributions are necessary to corroborate our findings. 
Owing to the small size of the established subgroups, future research on group work is necessary on a more representative number of students, both according to their culture and gender. In addition, instead of considering international students as a rather homogenous group, future studies need to consider

\section{REFERENCES}

1. Blatchford, P., Kutnick, P., Baines, E., and Galton, M. (2003). Toward a social pedagogy of

2. classroom group work, International Journal of Educational Research, 39(12), 153-172.

3. Bolton, M. K. (1999). The role of coaching in student teams: A 'just-intime' approach to learning, Journal of Management Education, 23(3), 233-250.

4. Cattani, G., Ferriani, S., Mariani, M., and Mengoli, S. (2013). Tackling the 'Galácticos' effect: Team familiarity and the performance of star-studded projects, Industrial and Corporate Change, 22(6), 1629-1662.

5. Chowdhury, S., Endres, M., and Lains, T.W. (2002). Preparing students for success in team work environments: The importance of building confidence, Journal of Managerial Issues, 14(3), 346-359.

6. Collins, N., Chou, Y.M., Warner M., and Rowley, C. (2017). Human factors in East Asian virtual teamwork: A comparative study of Indonesia, Taiwan and Vietnam, The International Journal of Human Resource Management, 28 (10), 1475-1498.

7. Curran, V.R., Sharpe, D., Forristall, J., and Flynn, K. (2008). Attitudes of health sciences students towards interprofessional teamwork and education, significant number of students coming from different European countries. Finally, female students represented a majority in our study. Therefore, future studies need to include a larger number of male students to obtain more representative results regarding gender diversity.

Learning in Health and Social Care, 7(3), 146-156.

8. Duus R., and Cooray M. (2014). Together we innovate: Cross-Cultural teamwork through virtual platforms. Journal of Marketing Education, 36(3), 244-257.

9. Dwyer, S., Orlando, C.R., and Chadwick, K. (2003). Gender diversity in management and firm performance: The influence of growth orientation and organizational culture, Journal of Business Research, 56(12), 1009-1019.

10. Ettington, D. R., and Camp, R. (2002). Facilitating transfer of skills between group projects and work teams, Journal of Management Education, 26(4), 356-380.

11. Falls, I., Bahhouth, V., Chuang, C.M., and Bahhouth, J. (2014). Factors Influencing Students' Perceptions of Online Teamwork, SAGE Open, 1-9.

12. Frobel, P., and Marchington, M. (2005). Team working structures and worker perceptions: A cross national study in pharmaceuticals, The International Journal of Human Resource Management, 16(2), 256-276.

13. Fruchtner, R. (2001). Dimensions of teamwork education, International Journal of Engineering Education, 17(6), 426-430.

14. Gist, M.E., and Mitchell, T.R. (1992). Self-efficacy: A theoretical analysis of its determinants and malleability, Academy of Management Review, 17(2), 182-211. 
15. Goold, A., Augar, N.,and Farmer, J. (2006). Learning in virtual teams: Exploring the student experience, Journal of Information Technology Education, 5, 477-490.

16. Gottschall H. and M. García-Bayonas. (2008). Student attitudes towards group work among undergraduates in business administration, education and mathematics, Educational Research Quarterly, 32(1), 3-28.

17. Gressgård, L.J. (2011). Virtual team collaboration and innovation in organizations, Team Performance Management: An International Journal, 17 (1/2), 102-119.

18. Guzzo, R.A., and Dickson, M.V. (1996). Teams in organizations: Recent research on performance and effectiveness, Annual Review of Psychology, 47, 301-338.

19. Halcomb, E.J., Gholizadeh, L., Digiacomo, M., Phillips, J., and Davidson, P.M. (2007). Literature review: Considerations in undertaking focus group research with culturally and linguistically diverse groups, Journal of Clinical Nursing, 16, 1000-1011.

20. Henneman, E.A., Lee, J.L., and Cohen, J.I. (1995). Collaboration: A concept analysis, Journal of Advanced Nursing, 21,103-109.

21. Hodge, K.A., and Lear, J.L. (2011). Employment skills for 21st century workplace: the gap between faculty and student perceptions, Journal of Career and Technical Education, 26(2), 26-41.

22. Hollenbeck, J.R., Beersma, B., Schouten, M., and Maartje, E.S. (2012). Beyond team types and taxonomies: a dimensional scaling conceptualization for team description, Academy of Management Review, 37(1), 82-106.

23. Katinka, J. A. H. P., van Eijs, P. W. LJ., Boshuizen, H. P. A., van der Vleuten, C. P. M., and Scherpbier A.J. J. A. (2005). General competencies of problem-based learning (PBL) and non-PBL graduate, Medical Education, 39(4), 394-401.

24. Kavanagh, M. H., and Drennan, L. (2008). What skills and attributes does an accounting graduate need? Evidence from student perceptions and employer expectations, Accounting \& Finance, 48, 279-300.

25. Landy, F. (1989). Psychology of Work Behavior, Pacific Grove, CA: Brooks/Cole.

26. LePine, J.A., Piccolo, R. F., Jackson, C. L., Mathieu, J. E., and Saul, J.R. (2008). A meta-analysis of teamwork processes: Tests of a multidimensional model and relationships with team effectiveness criteria, Personnel Psychology, 61(2), 273-307.

27. Ludford, P., Cosley, D., Frankowski, D., and Terveen, L. (2004). Think different: increasing online community participation using uniqueness and group dissimilarity Proceedings of the SIGCHI Conference on Human Factors in Computing Systems, pp. 631-638.

28. McCorkle, D.E., Reardon, J., Alexander, J.F., Kling, N.D., Harris, R.C., and Vishwanathan, I. (1999). Undergraduate marketing students, group projects and teamwork: The good, the bad and the ugly, Journal of Marketing Education, 21(2), 106-117.

29. Molyneux, J. (2001). Interprofessional teamworking: what makes teams work well? , Journal of Interprofessional Care, 15, 29-35.

30. Nancarrow, S. A., Booth, A., Ariss, S., Smith, T., Enderby, P. and Roots, A. (2013): Ten principles of good interdisciplinary team work, Human Resources for Health, 11-19.

31. Nell, C.E., and Cant, M.C. (2014). Determining student perceptions regarding the most important service features and overall satisfaction with the service quality of a higher education institution. 
Management: Journal of Contemporary Management, 19 (2), 63-87.

32. Nunnally, J.C., and Bernstein, I.H. (1994). Psychometric theory, 3rd ed., New York, NY: McGraw Hill.

33. Panina, D. and Kroumova, M. (2015). Cross-cultural communication patterns in computer mediated communication. Journal of International Education Research, 11(1), 1-5.

34. Peslak, A.R. (2005). Emotions and team projects and processes, Team Performance Management, 11(7/8), 251-262.

35. Pineda, R.C., Barger, B., and Lerner, L.D. (2009). Exploring differences in student perceptions of teamwork: The case of U.S. and Lithuanian Students, Journal of International Business and Cultural Studies, 1, 50-58.

36. Powell, A, Piccoli, G. and Ives, B. (2004). Virtual teams: A review of current literature and directions for future research, The DATA BASE for Advances in Information Systems, 35 (1), 6-36.

37. Ritchie, J., Lewis, J., and Elam G. (2003). Designing and selecting samples. In Qualitative research practice: A guide for social science students and researchers, J. Ritchie and Lewis, J. (Eds.), pp. 77-108

38. Ruiz Ulloa, B. C., and Adams, S. G. (2004). Attitude toward teamwork and effective teaming, Team Performance Management, 10(7/8), 145-151.

39. Šerić, M., and Garbin Praničević, D. (2017). University students' attitudes toward teamwork: A cross-cultural study. EDULEARN17 Proceedings: IATED, 2017, 9th annual International Conference on Education and New Learning Technologies, pp. 5807-5813. ISBN: 978-84-697-3777-4.

40. Takeuchi, J., Kass, S.J., Schneider, S.K., and VanWormer, L. (2013). Virtual and face-to-face teamwork differences in culturally homogeneous and heterogeneous teams, Journal of Psychological Issues in Organizational Culture, 4(2), 17-34.

41. Terveen, L. and McDonald, D. (2005). Social matching: A framework and research agenda, ACM Transactions on Computer Human Interaction, 12(3), 401-434.

42. Van Knippenberg, D., De Dreu, C.K.W. and Homan, A.C. (2004). Work group diversity and group performance: An integrative model and research agenda, Journal of Applied Psychology, 89(6), 1008-1022.

43. West, M.A. (2012). Effective teamwork: Practical lessons from organizational research, John Wiley \& Sons, Third Edition.

44. Young, M.L. (2009). Building relationships in project management, retrieved from https://www.projectsmart.co.uk/ building-relationships-in-project-management.php (accessed June 16, 2017).

45. Zijlstra, F.R.H., Waller, M.J., and Phillips, S.I. (2012). Setting the tone: Early interaction patterns in swiftstarting teams as a predictor of effectiveness, European Journal of Work and Organizational Psychology, 21(5), 749-777. 


\section{UPRAVLJANJE GRUPNIM RADOM U UČIONICI: MEĐUNARODNA STUDIJA PERCIPIRANIH KORISTI I RIZIKA, UTEMELJENA NA KULTURI I SPOLU STUDENATA}

\section{SAŽETAK}

Rad u grupama je postao ključnim čimbenikom uspjeha organizacija u globalnom gospodarstvu. Stoga poslovni sektor institucijama visokog obrazovanja postavlja imperativ modificiranja studijskih programa i pripremanja istih za efektivan rad u timovima. Međutim, dok se studenti značajno potiču na timski rad, njihovo mišljenje o ovoj praksi ostaje relativno zanemareno. Nadalje, uloge kulture i spola u studentskoj percepciji grupnog rada nisu privukle veću pozornost istraživača. Cilj je ove studije istražiti studentsku percepciju grupnog rada, u smislu njegovih koristi i rizika, kao i utvrditi moderiraju li kultura $i$ spol navedene percepcije. U istraživanju su korištene kvalitativne $i$ kvantitativne metode. Podaci su prikupljeni među španjolskim, hrvatskim $i$ medunarodnim studentima, na dva europska sveučilišta: Sveučilištu u Valenciji, u Španjolskoj, te Sveučilištu u Splitu, u Hrvatskoj. Rezultati istraživanja sugeriraju da, iako studenti percipiraju koristi od grupnog rada, također smatraju da postoje i brojni rizici (a naročito hrvatski studenti). Navedeno bi moglo biti razlog zašto isti ne iskazuju preferenciju grupnog pred individualnim radom, bez obzira na kulturu i spol. 